\title{
DEEP IN THE SHED: THE DISCOURSE OF
}

\section{AFRICAN-AMERICAN CINEMA}

Todd E. Boyd

ELVIS, HE WAS a hero to most, but he never meant shit to me, you see, straightout racist, the sucker was simple and plain, motherfuck him and John Wayne.

- Public Enemy

The polemical poets, Public Enemy, have in the above sentence conducted a most rigorous critique of American culture and society within the twentieth century. Having deconstructed two of the most prolific icons of white male supremacy, Public Enemy demonstrates what I see as the primary task of African-American intellectual activity, the rewriting of American history, society, and culture with a black pen. Whereas traditional definitions of intellectual activity revolve around a specifically logocentric white male definition, which primarily argues that intellectuals somehow come from various academic institutions, African-American intellectuals, because of an obvious denial to the academic means of production, have emerged from certain circumscribed places within the society and exist as products of an oral culture, which functions in direct opposition to white Western literate culture. According to Cornel West:

$[\mathrm{T}]$ here are two organic intellectual traditions in Afro-American life: The Black Christian Tradition of Preaching and The Black Musical Tradition of Performance. Both traditions, though undoubtedly linked to the life of the mind, are oral, improvisational, and histrionic. (114)

West seems to totalize the intellectual tradition by reducing it down to these two poles, denying the inclusion of Paul Robeson or Malcolm X, for instance. Yet, what seems interesting in this assertion regards the thrust of an American hegemonic exclusionary practice, which has only allowed for articulation in the realm of Eurocentric Christianity and black musician performing for a primarily white-owned music industry.

How do we then begin to theorize about those instances of black 
intellectual expression which exist outside of the two dominant traditions mentioned by West? My concerns in this paper involve exploring the cinema as an act of black intellectual activity. Black cinema, within American society, especially recent examples, such as the films of Spike Lee or Robert Townsend, utilizes the combination of a technologized visual medium, with tenets specific to black oral tradition, to create a cinema that articulates and rearticulates, establishing an Afrocentric discourse that challenges the dominant white discourse on blacks in American society:

Any film whose signifying practices or whose making of symbolic images emanates from an essential cultural matrix deriving from a collective black socio-cultural and historical experience and uses black expressive traditions as a means through which artist languages are mediated. (Yearwood 70-71)

Two of the most important eras of black intellectual activity have been the Harlem Renaissance of the 1920s and the Black Aesthetic Movement of the late $60 \mathrm{~s}$ and early $70 \mathrm{~s}$. In both time periods, the ideological function of artist products stood at the forefront of most discussions. Yet the cinema remains visibly absent from both eras. In the two most recognized anthologies chronicling the respective movements, The New Negro and The Black Aesthetic, the cinema does not exist.

In the case of the 1920s, film as an art form existed in its infancy. This is only thirty some odd years since the exhibition of the first film and only twenty-two years after the exhibition of The Great Train Robbery, the film considered to be the first narrative film. Black film production during the 1920 s was either sporadic or involved the production of films that used entirely black casts and were directed at primarily black audiences, but were produced by white-owned independent companies. Therefore, not only did film exists as a relatively new artist form as far as the society at large was concerned, but the relative dearth of black films by black directors and producers, authorial identity being a component of both eras, inhibited the inclusion of film as viable political weapon in the expression of the New Negro. Not only that, but Oscar Micheaux, the most prolific black director/producer of the 20s, and any subsequent period for that matter, worked in the Midwest, while the Harlem Renaissance took place in the East, creating a financial and geographical obstacle for the unity of these two practices.

The arguments presented about the Harlem Renaissance seem incompatible with the time period for the Black Aesthetic movement. By the 1960s film had certainly etched an indelible mark on American cultural history. Even though black cinematic production had not achieved the commercial success of its larger white counterpart, it did 
by this time exist. One wonders why a film like Sweetsweetback's Baddass Song did not make the pages of the Gayle edited text. The insertion of film into this period of black intellectual activity, or better yet, the exclusion of film, stands as a concern of historical inquiry which should be discussed further, but exists beyond the scope of this paper.

I would like to postulate a theory of black cinematic discourse in the absence of a culturally generated one from the time periods already discussed. Black cinema can be described as a syncretic process. Paul Gilroy states:

Black expressive cultures affirm while they protest. The assimilation of blacks is not a process of acculturation, but of cultural syncretism. Accordingly, their selfdefinitions and cultural expressions draw on a plurality of black histories and politics. (155)

Black cinema combines the technological medium of film, rooted in Western technology, with certain components of black oral tradition. The use of the technology affirms, while the reliance on the oral expressivity protests against.

This process of cultural syncretism can be seen as best exemplified through the idiom of jazz. Early attempts at producing jazz, for example, Buddy Bolden playing the cornet in a New Orleans marching band in the late 1800 s, combine Western literate music, with various rhythmic stylizations directly from African tradition. The use of the African musical style, based on the culture of orality, rearticulates the manner in which music had been played up until that time. The oral segment of the music provides the protestation against Western literate music:

It could be said with a certain amount of accuracy that oral culture was, by nature, an underground culture, in the context of literate America; that simply being a

Negro in America was grounds for nonconformity. (Sidran 80)

Similar incidents of jazz as protest emerge in the context of Be-bop jazz, where black musicians like Charlie Parker, Dizzy Gillespie, and Kenny Clarke alter what had been foregrounded as mainstream jazz, Swing, embodied by white musicians like Benny Goodman. When the dominant culture attempted to define, black oral culture redefined.

Following the Be-bop revolution, a series of white jazz musicians attempted to, once again, move the definition of jazz to a position outside of the black idiom. West Coast, or "cool" jazz, emerged. Initially, Miles Davis made an album entitled The Birth of the Cool in 1949. Adapting the "cool" label from Davis a series of white jazz musicians began to perform this "cool" jazz, yet this music sounded totally different from the music performed on the Davis album. Also, the move to the West Coast becomes significant because of its geographical distance from Harlem, the place where Be-bop and the 
black musicians existed. So not only does the music become saccharinized, but the actual move away from Harlem signals another attempt at taking the music outside of oral culture.

Once again, black musicians redefined the idiom by inventing a style of music that reverted back to a specifically blues or "soul" idiomatic style. The pianist, Horace Silver, and the group he was at one time associated with, the Jazz Messengers featuring drummer Art Blakely, personify the blues/soul approach. This foregrounding of an earlier form of black oral tradition mediated through the Western technological instruments demonstrates the syncretic qualities of jazz at its best:

The Jazz Messengers, above all, stressed the ability to play the blues. They thus further stressed the advancement of techniques valid only in terms of an oral approach. The blues techniques developed by black jazz musicians often appeared unschooled, yet they were, in terms of good blues playing, superior techniques. As the black culture began to accept the validity of uniquely black solutions to problems of structure and content and as these solutions gained greater exposure, a combination of confidence and outrage-unparalleled in black American history-developed. It was on the basis of this new aggressiveness-as represented by the "soul" phenomenon - that many politically active Negroes gained the confidence to claim that integrationist trends in America, for example, were potentially misdirected. (Sidran 132)

This same trend can be seen in black cinema, that of definition/ redefinition. For instance, the attempt to define the question of blacks in American society through film by The Birth of a Nation (1915) was championed by then president Woodrow Wilson as "history written in lightning." After the release of this film, Emmet J. Scott, secretary for Booker T. Washington, set out to redefine this question by producing The Birth of a Race. Though this film in its final release was totally different than its initial intention, the act itself constitutes a rejection of the white definition of blackness.

Another example of this syncretic process can be seen in the Spike Lee film She's Gotta Have It. This film foregrounds the oral nature of black cinema. The first scene of the film is a quote from the Zora Neale Hurston novel Their Eyes Were Watching God. Immediately following this scene we see a series of black images in still photograph. Then the film's main character, Nola Darling, shot straight on, much like a "talking head" in a television news segment, directly addresses the spectators. Their dialogue can be summed up as an attempt to "clear her name." She closes out the conversation with a phrase from black vernacular, "This was the deal." We have heard "Nola's story" in a specifically oral manner. In traditional Hollywood cinema, characters are introduced through the context of the film, their actions serve to define them. Whereas, in this film characters introduce themselves through oral discourse. Thus, the orality of African-American story- 
telling has been combined with the visuals of cinema.

This cinematic practice demonstrated by Spike Lee helps to create a vernacular cinema, in the sense that it deviates from the standard cinematic language of Hollywood. Houston Baker states:

The vernacular in relation to human beings signals "a slave born on his master's estate." In expressive terms, vernacular indicates "arts native or peculiar to country or locale." The material conditions of slavery in the United States and the rhythms of Afro-American blues combined and emerged from my revised materialistic perspective as an ancestral matrix that has produced a forceful and indigenous American creativity. (2)

Black cinema, as it combines the technology of Western society with aspects of black oral culture, must also develop a critical apparatus that looks to explicate these oral tendencies, or as Henry Louis Gates, Jr. has stated in another context, the signifying black difference. Attempts to critique black cinema on "white" terms place the cinematic text on a critical "Procrustean bed," eliminating that which exists as specific to black culture and focusing on simply the film as text, instead of as an instance of black cultural expressivity.

An example of a new critical approach to black cinema can be seen in an episode from Robert Townsend's Hollywood Shuffle. Instead of At the Movies, the Siskell and Ebert movie review program, we get Sneakin in the Movies, movies critiqued by some "real brothers." The content of this entire scene revolves around a criticism of "white" films from a black vernacular perspective. For instance, one movie, entitled Amadaeus Meets Salarious, is given "the finger," because, in the words of the critic, "I'm sick of movies that I can't pronounce the title. A muthafucker got to be able to tell his woman where he gonna take her." Though comical, the scene demonstrates the need for criticism of black films which pays attention to the intricacies of black cultural and cinematic discourses.

This paper can only be seen as a preliminary attempt at a theorization of the question of race in American cinema and culture. What seems most interesting about this project revolves around the combination of a Western technological phenomenon, the cinema, and black oral discourse. Because of the means of production in cinema being at times unattainable, the production of black cinematic texts appears sporadically. When these texts do appear, they are often denied distribution on a massive scale, thus limiting the exhibition of these films to art house and film festival circuits, and limiting their audience to a select few black and white bourgeois. This, I argue, makes these films less useful for a theorization of black cinema, because inherent in this theorization is an impulse to theorize black spectatorship as well. If only a few people see the films, what happens to a collective black struggle? This paper only scratches the surface of 
what I see as a larger project, that of relating black intellectual output, cultural discourse, and cinematic production and reception in a larger social and political context.

\section{WORKS CITED}

Baker, Houston. Blues, Ideology, and African-American Literature: A Vernacular Theory. Chicago: U of Chicago P, 1984.

Gates, Henry Louis, Jr. "Talking That Talk." "Race," Writing, and Difference. Ed. Henry Louis Gates, Jr. Chicago: U of Chicago P, 1984.

Gayle, Addison, Jr., ed. The Black Aesthetic. Garden City, NY: Doubleday, 1971.

Gilroy, Paul. There Ain't No Black in the Union Jack: The Cultural Politics of Race and Nation. London: Hutchinson P, 1987.

Gladstone, Yearwood. "Towards a Theory of Black Cinema Aesthetics," Black Cinema Aesthetics. Athens, OH: Ohio U Center for Afro-American Studies, 1982. Locke, Alain, ed. The New Negro. New York: Atheneum P, 1986.

Sidran, Ben. Black Talk. New York: Decapo P, 1983.

West, Cornel. "The Dilemma of the Black Intellectual." Cultural Critique Spring 1986. 
